NASA/TM-2001-210606

\title{
High Temperature Mechanical Behavior of Polycrystalline Alumina From Mixed Nanometer and Micrometer Powders
}

Jon C. Goldsby

Glenn Research Center, Cleveland, Ohio 
Since its founding, NASA has been dedicated to the advancement of aeronautics and space science. The NASA Scientific and Technical Information (STI) Program Office plays a key part in helping NASA maintain this important role.

The NASA STI Program Office is operated by Langley Research Center, the Lead Center for NASA's scientific and technical information. The NASA STI Program Office provides access to the NASA STI Database, the largest collection of aeronautical and space science STI in the world. The Program Office is also NASA's institutional mechanism for disseminating the results of its research and development activities. These results are published by NASA in the NASA STI Report Series, which includes the following report types:

- TECHNICAL PUBLICATION. Reports of completed research or a major significant phase of research that present the results of NASA programs and include extensive data or theoretical analysis. Includes compilations of significant scientific and technical data and information deemed to be of continuing reference value. NASA's counterpart of peerreviewed formal professional papers but has less stringent limitations on manuscript length and extent of graphic presentations.

- TECHNICAL MEMORANDUM. Scientific and technical findings that are preliminary or of specialized interest, e.g., quick release reports, working papers, and bibliographies that contain minimal annotation. Does not contain extensive analysis.

- CONTRACTOR REPORT. Scientific and technical findings by NASA-sponsored contractors and grantees.
- CONFERENCE PUBLICATION. Collected papers from scientific and technical conferences, symposia, seminars, or other meetings sponsored or cosponsored by NASA.

- SPECIAL PUBLICATION. Scientific, technical, or historical information from NASA programs, projects, and missions, often concerned with subjects having substantial public interest.

- TECHNICAL TRANSLATION. Englishlanguage translations of foreign scientific and technical material pertinent to NASA's mission.

Specialized services that complement the STI Program Office's diverse offerings include creating custom thesauri, building customized data bases, organizing and publishing research results ... even providing videos.

For more information about the NASA STI Program Office, see the following:

- Access the NASA STI Program Home Page at http://www.sti.nasa.gov

- E-mail your question via the Internet to help@sti.nasa.gov

- Fax your question to the NASA Access Help Desk at 301-621-0134

- Telephone the NASA Access Help Desk at 301-621-0390

- Write to: NASA Access Help Desk NASA Center for AeroSpace Information 7121 Standard Drive Hanover, MD 21076 
NASA/TM-2001-210606

\section{High Temperature Mechanical Behavior of Polycrystalline Alumina From Mixed Nanometer and Micrometer Powders}

Jon C. Goldsby

Glenn Research Center, Cleveland, Ohio

National Aeronautics and

Space Administration

Glenn Research Center 


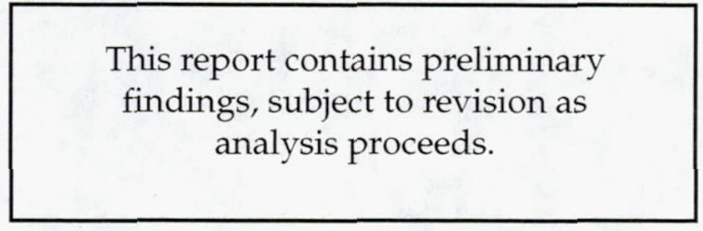

Available from

NASA Center for Aerospace Information 7121 Standard Drive Hanover, MD 21076
National Technical Information Service 5285 Port Royal Road Springfield, VA 22100 


\title{
HIGH TEMPERATURE MECHANICAL BEHAVIOR OF POLYCRYSTALLINE ALUMINA FROM MIXED NANOMETER AND MICROMETER POWDERS
}

\author{
Jon C. Goldsby \\ National Aeronautics and Space Administration \\ Glenn Research Center \\ Cleveland, Ohio 44135
}

\begin{abstract}
SUMMARY
Sintered aluminum oxide materials were formed using commercial methods from mechanically mixed powders of nano- and micrometer alumina. The powders were consolidated at 1500 and $1600{ }^{\circ} \mathrm{C}$ with 3.2 and $7.2 \mathrm{ksi}$ applied stress in argon. The conventional micrometer sized powders failed to consolidate. While 100 percent nanometer-sized alumina and its mixture with the micrometer powders achieved $>99$ percent density. Preliminary high temperature creep behavior indicates no super-plastic strains. However high strains $(>0.65$ percent) were generated in the nanometer powder, due to cracks and linked voids initiated by cavitation.
\end{abstract}

\section{INTRODUCTION}

Nanometer-sized ceramic powders are currently being investigated for the preparation of adhesive and joining technology for high temperature structural oxide based ceramic matrix composites, and as both functional and substrate material in the electronic ceramics industry (refs. 1 to 3). Among the benefits cited for use of small particle size starting powders are the lower temperatures needed for full densification and superplastic formability (ref. 4). However these same properties reduce creep and high temperature mechanical integrity, which result in poor high temperature mechanical properties. One possible solution is to alloy the larger powders with nanometer sized powder to take advantage of the lower temperature formability while allowing the micrometer-sized powders to maintain high temperature mechanical integrity. Standard ceramic powder consolidation involves mixing various powder sizes to obtain high packing densities, where maximum packing densities for closed packed tetrahedral or pyramidal uniform spheres are 74 percent (ref. 5). Increasing the packing density with smaller particles of the same composition should enhance sintering by reducing voids and increasing the effective area between the larger particles thus allowing more rapid mass transport. It is the purpose of this investigation to compare the effect of temperature and stress on aluminum oxide monoliths produced from mechanically mixed nanometer and micrometer sized alumina powders.

\section{EXPERIMENTAL}

Various volume fractions of alumina powder with $<28$ nanometer average particle size were milled with micrometer particle size alumina powder in alcohol. The weights fractions of the mixtures as well as their designations are given in table I. Powder mixtures were dried, and with no sintering aids or binders, separately hot-pressed in a rectangular 13 by $128 \mathrm{~mm}$ graphite die at 1500 and $1600{ }^{\circ} \mathrm{C}$ with externally applied stresses of 20 and $48 \mathrm{MPa}$ in an argon atmosphere for $20 \mathrm{~min}$. Each sample was furnace cooled to ambient temperature. Samples were then machined for testing. Typical sample dimensions were 127 by 4.5 by $13.5 \mathrm{~mm}$. Selected portions were placed in a separate furnace and heated in air to $1200{ }^{\circ} \mathrm{C}$ for $4 \mathrm{hr}$, then used for density measurements using the Archimedes method. Samples for creep testing were heated treated directly in the test furnace at $1200^{\circ} \mathrm{C}$ in air for four hours before testing.

Creep experiments were performed in four-point bend using $1 / 4$ point loading using recommendations from ASTM subcommittee C28.07. Creep test were performed in air with externally applied stresses of 40 and $100 \mathrm{MPa}$ with a $20 / 40$ span. Test temperatures were 1100 and $1200^{\circ} \mathrm{C}$. A detailed description of the testing protocol is found in (ref. 6).

Two representative samples, the first in the as-pressed condition and the second, after annealing of the 100/0 material, were mounted and hand polished using standard metallographic techniques. Great care was 
used in sample preparation to avoid metal impurities from polishing media, however hand polishing resulted in some grain pullout. TEM slices were prepared from $0.5 \mathrm{~mm}$ wafers, then finally ion milled to $80 \mu \mathrm{m}$. The samples were then carbon coated and examined using a JEOL 6100 scanning electron microscope while electron transmission microscopy was performed on a Philips EM400T operating at $120 \mathrm{keV}$. Phases were identified from X-ray diffraction patterns.

\section{RESULTS AND DISCUSSION}

The powders demonstrated good handling integrity and consolidated well. Samples appeared dark gray externally as well as internally, which suggest neither carbon diffusion or oxygen deficiency due to the vacuum hot press consolidation sequence. Annealing in air resulted in all samples turning white starting from the surface and progressing to the interior of the sample. Although alumina oxide samples were hot pressed at $1200{ }^{\circ} \mathrm{C}$ from nanometer starting powders, grain growth resulted in grain sizes from 2 to $10 \mu \mathrm{m}$ in the $100 / 0$ mixture. The grain boundaries appear free of any secondary phases. There was no evidence of exaggerated grain growth. Figure 1 shows an annealed 50/50 mixture processed at $1500{ }^{\circ} \mathrm{C}$ with evidence of tangled dislocations resulting form the hot press process. X-ray diffraction results reveal all samples to be $>95$ percent $\alpha-\mathrm{Al}_{2} \mathrm{O}_{3}$, meaning that all transition alumina was stabilized as a result of the thermal exposures of the fabrication process.

Typical results of flexural creep are seen in figure 2. Post-crept samples appeared white with evidence of crushing damage at the loading points for the high fraction ( $>50$ percent) nanometer-powders. High temperature behavior can be separated into three regions including an elastic strain component at $1100{ }^{\circ} \mathrm{C}$ and creep deformation composed of primary and steady state behavior. However, at the same stress level at $1200{ }^{\circ} \mathrm{C}$, creep strain increased exponentially. Creep strain increased with increasing volume fraction of nanometer sized powder with the $0 / 100$ material giving the least amount of strain at all times and temperatures. Observations of the post-crept sample composition 10/90 shows evidence of creep deformation resulting from cavity link-up of voids after the $1200{ }^{\circ} \mathrm{C}$ creep tests, whereas the $90 / 10$ material displayed deformation resulting from crack growth with no evidence of cavity link-up. In some micrographs evidence suggests crack propagation along the larger grains terminating in a region of dislodged grains.

Figure 3 is the temperature dependent elastic and anelastic response of a polycrystalline alumina sample, produced from the $100 / 0$ mixture. While the measured grain size was $<10 \mu \mathrm{m}$, the internal friction remained below $10^{-3}$ in units of logarithmic decrement up to $1000{ }^{\circ} \mathrm{C}$ after which the internal friction values increased exponentially with respect to temperature. The resonance frequency response, a measure of elastic stiffness, decreases with temperature from $1141 \mathrm{~Hz}$ at room temperature to $1044 \mathrm{~Hz}$ at $1300{ }^{\circ} \mathrm{C}$ with an inflection point at $1050{ }^{\circ} \mathrm{C}$ indicating a departure from elastic behavior. The relatively high internal friction of nanometer-grain size alumina as reported by Xie, et al. (ref. 7) at low temperatures was not observed in the temperature dependent internal friction of this study, probably due to the highly dense and stable nature of the hot pressed sample 100/0 compared to the cold pressed materials of Xie's study, which remained in the transition, low density state. However figure 3 does show the onset of what is believed to be the grain boundary-sliding peak, for the same reason as those given for the larger grain material. Yu (ref. 8) performed internal friction studies on alumina polycrystals with unspecified impurity content or grain size at sub-]audio frequencies. They revealed the existence of a large anelastic peak, which they attributed to grain boundary sliding at a temperature and frequency consistent with the results of figure 3. While certainly not a conclusive mechanism it has been observed that the onset of interface reaction controlled creep of high purity alumina fibers also occurs near $1100{ }^{\circ} \mathrm{C}$ (ref. 9), hence grain boundary sliding controlled by diffusive interface reactions is the likely mechanism of high temperature deformation in these alumina mixtures.

\section{CONCLUSIONS}

Additions of nanometer-sized to micrometer-sized alumina powders allows higher packing densities, which aids in pressure assisted consolidation by enhancing diffusive interface interactions. Preliminary high temperature mechanical behavior indicates no super-plastic strains, however high strains ( $>0.65$ percent) were generated in the nanometer-sized powder, due to cracks and linked voids initiated by cavitation. 


\section{REFERENCES}

1. Holtz and V. Provenzano: Riehemann NanoStructerd Materials 7, iss. 8, 905(1996).

2. Olszna, P. Marchlewski, and K.J.: Kurzydlowski, Ceramics International 23,323 (1997).

3. Ferkel and W. Riehemann: NanoStructerd Materials 7, no. 8, 835(1996).

4. Locatelli, B.J. Dsalgleish. K. Nakashima, A.P. Tomsia, and A.M. Glaeser: Ceramics International 23,313 (1997).

5. Reed: Introduction to the Principles of Ceramic Processing, p. 188 John Wiley \& Sons Inc. (1988).

6. A.C. Rosa, M.R. Gallas, and J.A.H. da Jornada: Ceramica 42, 275(1996).

7. Xie, C., Zhang, L., and Mo, C.: Nanaostructured Materials, 4, no. 1, 113, (1994).

8. Yu, A., Fedorov, O., Sysoev, O., Yu, S., Balashov, A. Sobolev, A, and Batygin, Izvestiya Akademii Nauk SSSR, Neorganicheskie Materialy, 10, no. 1,112(1974).

9. Pysher, D.J. Ph. D.: Thesis Department of Materials Science and Engineering. The Pennsylvania State University, May 1992.

TABLE I.-POWDER MIXTURE COMBINATION
\begin{tabular}{|c|c|c|}
\hline Designation & $\begin{array}{c}\text { Nanometer-sized } \\
\text { pow der, } \\
\text { grams }\end{array}$ & $\begin{array}{c}\text { Micrometer-sized } \\
\text { powder, } \\
\text { grams }\end{array}$ \\
\hline $0 / 100$ & 0 & 30 \\
\hline $10 / 90$ & 3 & 27 \\
\hline $50 / 50$ & 15 & 15 \\
\hline $90 / 10$ & 27 & 3 \\
\hline $100 / 0$ & 30 & 0 \\
\hline
\end{tabular}




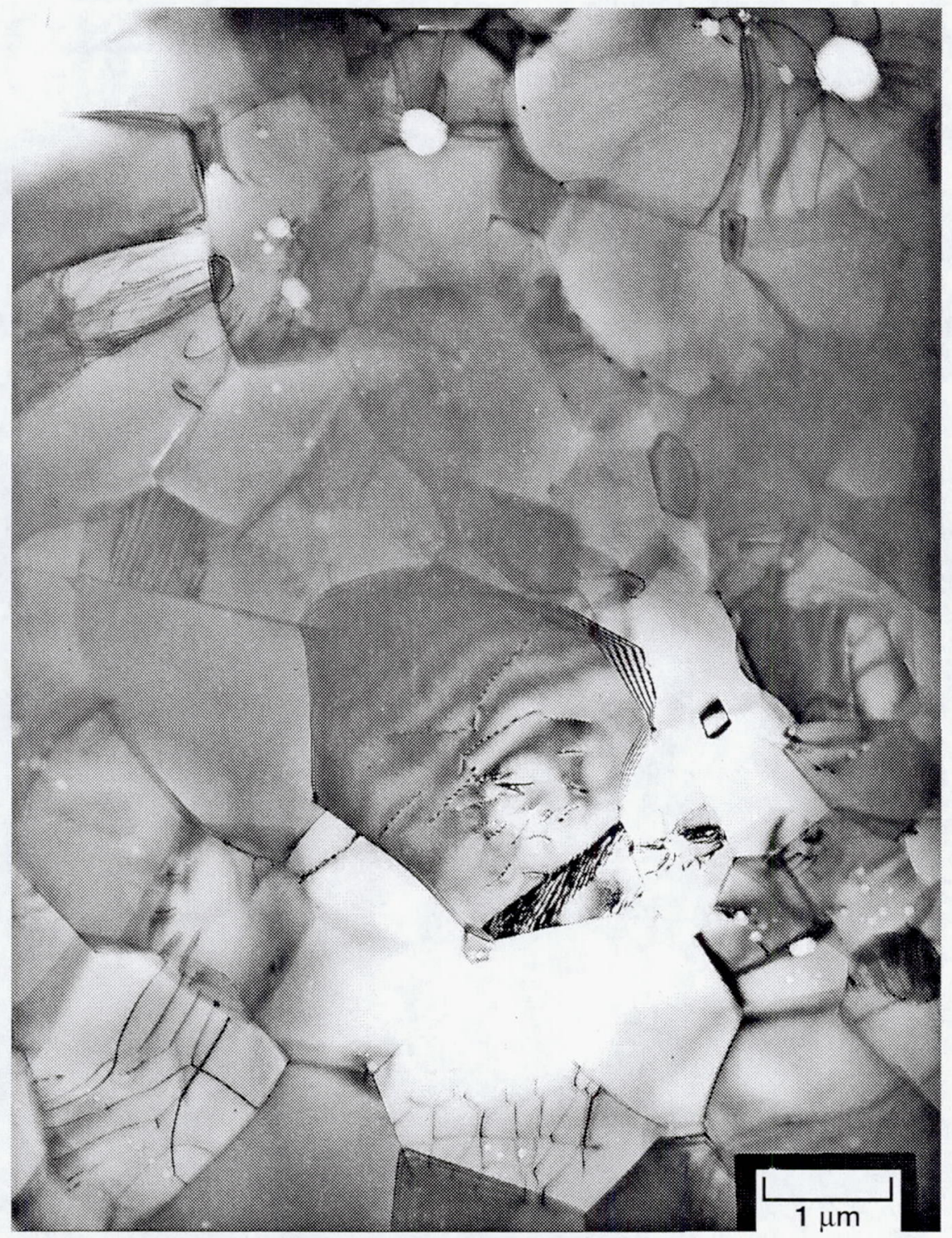

Figure 1.-Annealed mixture $(50 / 50)$ consolidated in argon at $1500{ }^{\circ} \mathrm{C}$ with $50 \mathrm{MPa}$ applied stress. Dislocation tangles result from the hot press process. 


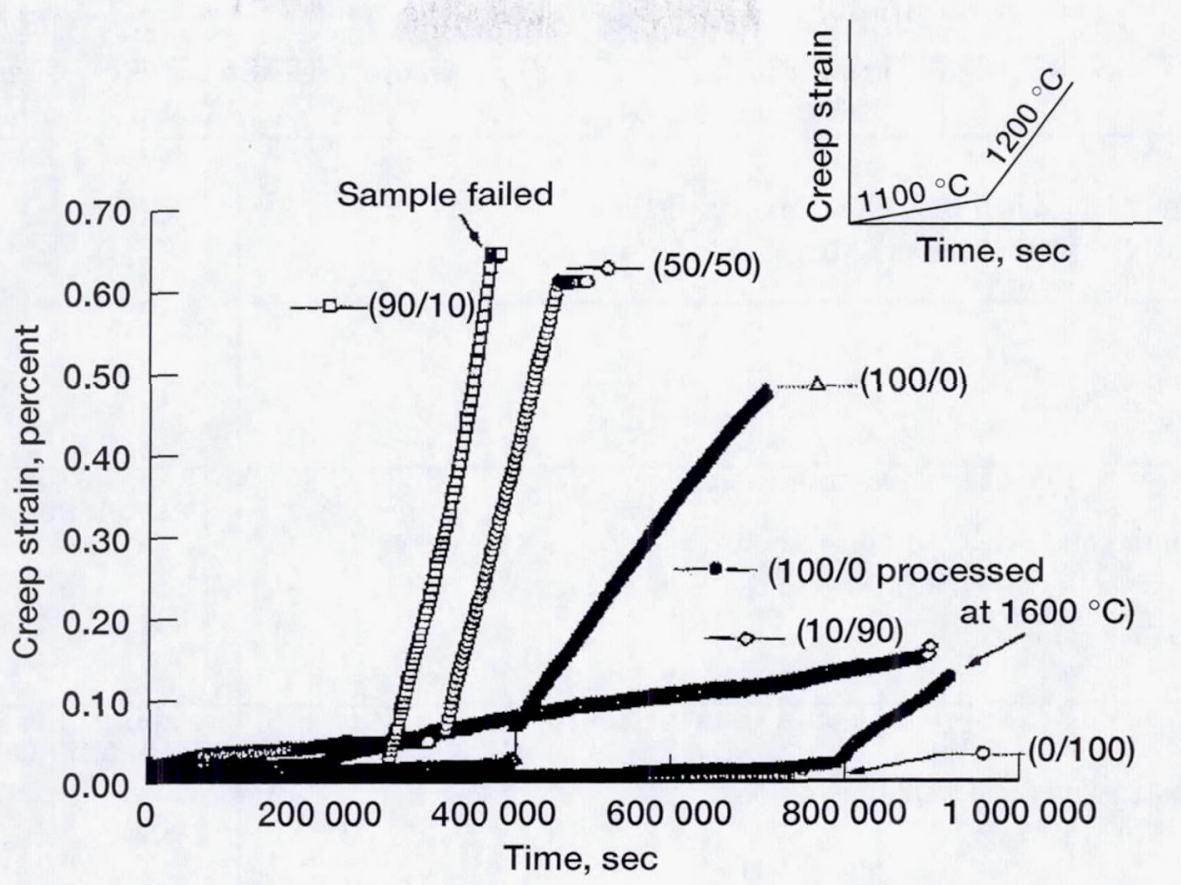

Figure 2.-Time dependent high temperature creep for various alumina mixtures in air at $1100{ }^{\circ} \mathrm{C}$ and $1200^{\circ} \mathrm{C}$ where the inset denotes the general change in creep strain with temperature increase as a function of time.

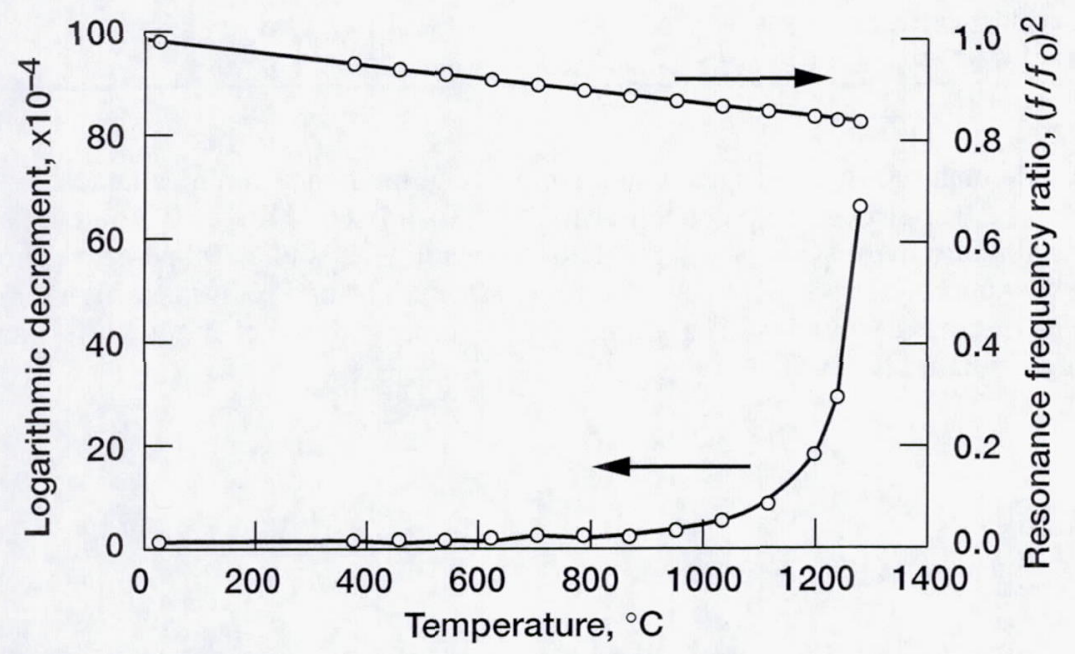

Figure 3.-Temperature dependent elastic and anelastic response of an alumina monolithic sample, sintered from nanometer size alumina powders $(100 / 0)$. 


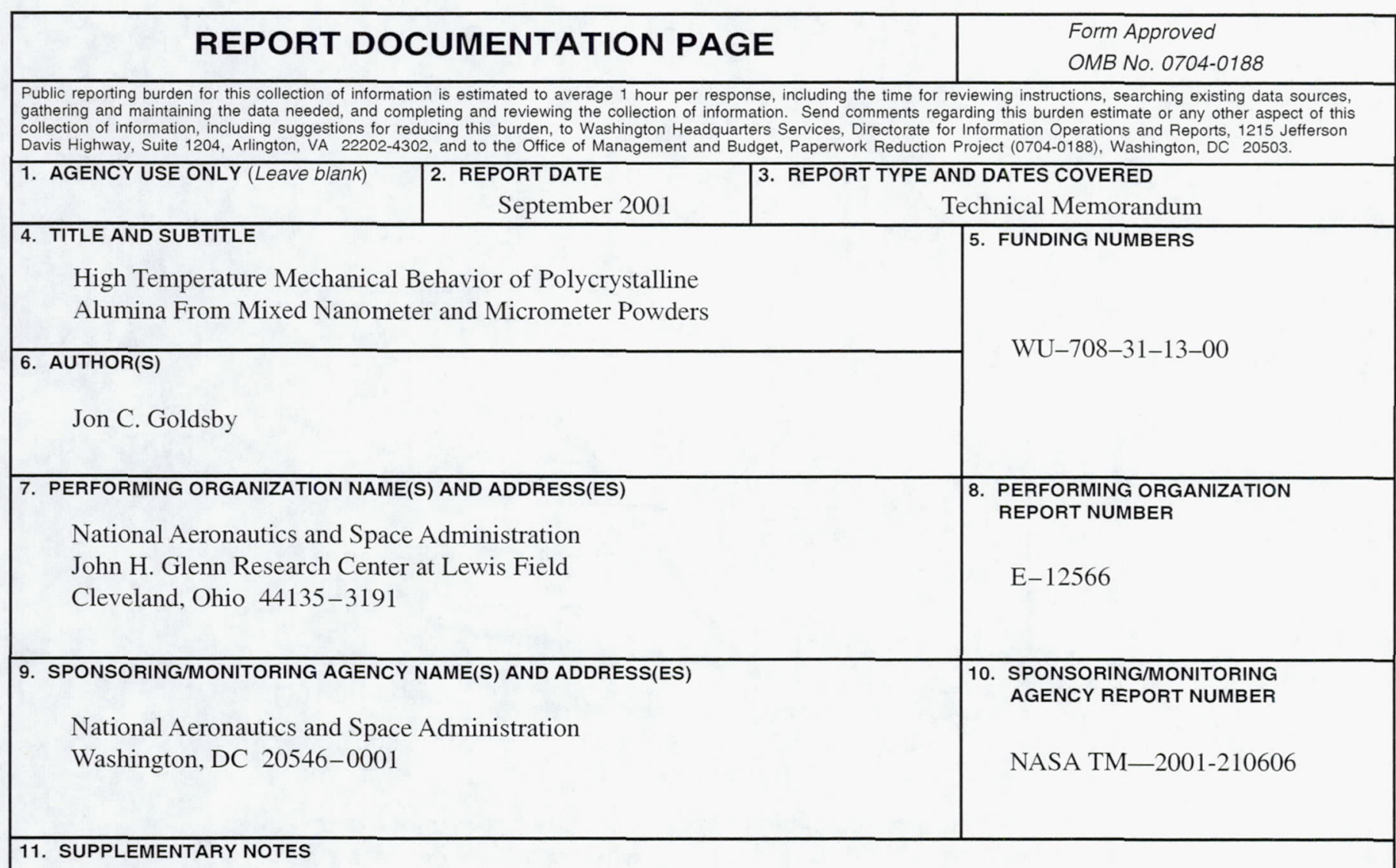

Responsible person, Jon C. Goldsby, organization code 5130, 216-433-8250.

12a. DISTRIBUTION/AVAILABILITY STATEMENT

12b. DISTRIBUTION CODE

Unclassified - Unlimited

Subject Categories: 24 and 27

Distribution: Nonstandard

Available electronically at http://gltrs. grc.nasa.gov/GLTRS

This publication is available from the NASA Center for AeroSpace Information, 301-621-0390.

13. ABSTRACT (Maximum 200 words)

Sintered aluminum oxide materials were formed using commercial methods from mechanically mixed powders of nanoand micrometer alumina. The powders were consolidated at 1500 and $1600{ }^{\circ} \mathrm{C}$ with 3.2 and $7.2 \mathrm{ksi}$ applied stress in argon. The conventional micrometer sized powders failed to consolidate. While 100 percent nanometer-sized alumina and its mixture with the micrometer powders achieved $>99$ percent density. Preliminary high temperature creep behavior indicates no super-plastic strains. However high strains ( $>0.65$ percent) were generated in the nanometer powder, due to cracks and linked voids initiated by cavitation.

14. SUBJECT TERMS

Nano-material; Alumina; Aluminum oxide; High temperature creep; Internal friction; Sonic elastic; Anelastic; Hot pressing; Mixing; $\mathrm{Al}_{2} \mathrm{O}_{3}$; Mechanical properties

\begin{tabular}{|c|c|c|}
\hline $\begin{array}{c}\text { 17. SECURITY CLASSIFICATION } \\
\text { OF REPORT } \\
\text { Unclassified }\end{array}$ & $\begin{array}{c}\text { 18. SECURITY CLASSIFICATION } \\
\text { OF THIS PAGE } \\
\text { Unclassified }\end{array}$ & $\begin{array}{c}\text { 19. SECURITY CLASSIFICATION } \\
\text { OF ABSTRACT } \\
\text { Unclassified }\end{array}$ \\
\hline
\end{tabular}

NSN 7540-01-280-5500 